\title{
GENETIC DIAGNOSTICS AND CLINICAL FEATURES OF WILSON'S DISEASE IN CHILDREN
}

\author{
Ivanna Haiboniuk ${ }^{1}$ \\ ivankagaiboniuk@gmail.com \\ Marta Dats-Opoka \\ Danylo Halytsky Lviv National Medical University \\ 69 Pekarska str., Lviv, Ukraine, 79010 \\ martadats@gmail.com \\ Halyna Makukh \\ makukh.h@ihp.lviv.ua \\ Yaryna Boyko ${ }^{2}$ \\ Western Ukrainian Specialized Children's Medical Centre \\ 27 Dnisterska str., Lviv, Ukraine, 79008 \\ jboyko@ukr.net \\ Igor Kiselyk \\ kiselyk@gmail.com \\ ${ }^{1}$ SI "Institute of Hereditary Pathology Ukrainian National Academy of Medical Sciences" \\ 31-a Lysenko str., Lviv, Ukraine, 79008 \\ ${ }^{2}$ Danylo Halytsky Lviv National Medical University \\ 69 Pekarska str., Lviv, Ukraine, 79010
}

\begin{abstract}
A disorder of copper metabolism at Wilson's disease (WD), conditioned by a mutation of adenosine thriphospate P-type gene $(A T P 7 B)$, results in irreversible changes in the liver and in the nervous system. Mortality is high at WD, but it is one of hereditary diseases, well subjected to the therapy. The disease is manifested in the early age, but its clinical course in children is symptomless that essentially complicates diagnostics. A single reliable method is genetic analysis for revealing mutations in $A T P 7 B$ gene.

The aim of the work was to analyze clinical manifestations and course of Wilson's disease cases, genetically verified in children by detecting mutations of $A T P 7 B$ gene.

The research group included children of 6-17 years old with different injury degrees of the hepatobiliary system. According to results of the molecular-genetic analysis, the most spread allele variant of $A T P 7 B$ gene (H1069Q) in Europe was confirmed in 10 patients of child age, including 4 cases of homozygosity.

In 10 cases of the confirmed diagnosis of Wilson's disease in child age in $100 \%$ (in all 10) of persons, a clinical manifestation was characterized by disorders from the hepatobiliary system, and only in $1(10 \%)$ - changes from the nervous system. At raising the level of transaminase in children, even at the normal bilirubin level and negative tests for viral hepatitis, it is recommended to carry out genetic testing for Wilson's disease.
\end{abstract}

Keywords: Wilson's disease, hepatobiliary disorders, children, genetic testing, mutation of ATP7B gene.

DOI: $10.21303 / 2504-5695.2020 .001197$

\section{Introduction}

Wilson's disease (WD), in the Russian literature - Wilson's-Konovalov or hepatocerebral dystrophy, - is a chronic hereditary disease with the autosomal-recessive inheritance, connected with disorders of hepatocellular copper metabolism, conditioned by the dysfunction of copperbinding AT-phase of P-type, coded by ATP7B gene [1].

According to the conducted meta-analysis of genetic studies, the prevalence of WD is 13.9 for 100000 , or 1 for 7194 [2] whereas the frequency of heterozygous carriage of mutations in $A T P 7 B$ gene is 1 for $90-150$ persons, although this pathology was earlier considered essentially rarer (1:3050 000). Ukraine doesn't have a united register of WD cases. WD is caused by the mutation of ade- 
nosine thriphosphate P-type gene (ATP7B) that is in chromosome 13q14. 3 and consists of 21 exons and 20 introns. The copper-binding AT-phase, coded by ATP7B gene is a group of transmembrane transport proteins of copper, mediating its metabolism. For the present, 600 pathogenic mutations are revealed in $A T P 7 B$ gene, and new ones are continuously found throughout the world [3, 4].

Wilson's disease is characterized by the high mortality, but it is one of hereditary diseases, well subjected to the therapy. Irreversible changes in tissues may be prevented at early diagnostics and treatment [5]. Initial stages of the disease are characterized with changes from functional hepatic samples, general weakness and appetite decrease. At later stages neurological changes join, heavier hepatic manifestations develop (chronic hepatitis, liver cirrhosis), and Kayser-Fleischer ring appears on the descemet membrane of the cornea [6-8]. Many cases of Wilson's disease are not diagnosed, because patients are observed for other diagnoses $[6,8]$.

Taking into account the progressive clinical course of Wilson's disease and possibilities of the effective therapy, an urgent problem is its early diagnostics, already in child age. There is no direct test for diagnosing Wilson's disease except genetic diagnostics, but the low level of ceruloplasmin and copper in blood, and also amount of copper, removed with urine for 24 hours (higher $100 \mathrm{mcg} / 24$ hours (1.6 mcmol/24 hours), together allow to make a conclusion about a copper amount in the organism, but we must remember that the high copper level in urine is not a pathognomonic sign of Wilson's disease, but this phenomenon is also observed at autoimmune hepatitis and cholestasis $[9,10]$.

Most patients demonstrated the light form of liver dysfunction, confirmed by the biochemical study by the increased level of bilirubin in blood, high activity of aspartate aminotransferase and alanine aminotransferase. At hard liver lesions, there can be observed the decreased albumin level. Despite the fact, that first symptoms appear in childhood, it is difficult to diagnose Wilson's disease at early stages. The clinical course in children is symptomless, and diagnostic criteria, established for adults [11], not always fit.

Only revelation of two mutations in $A T P 7 B$ gene allows to confirm the diagnosis of Wilson's disease genetically and to attribute 4 points by the point system WD ( 8 th International Meeting on Wilson's's disease, Leipzig 2001) to a patient [12].

According to the point system, all diagnostic criteria allow to reveal the disease, when the organism have already undergone serious lesions, fixed in changes of biochemical parameters of blood, just the increase of transminase (ALT, AST) levels, increase of the level of alkaline phosphatase, total bilirubin, copper level of blood serum and of daily urine, decrease of ceruloplasmin, appearance of Kayser-Fleischer ring (or its germs) on the eye cornea and other non-specific manifestations, such as aminociduria, nephrocalcinosis, cardiomyopathy and so on [13-15]

The diagnostic of Wilson's disease in child age often remains a clinical finding, but it must be accented, that the genetic defect is present from the moment of conception and influences the work of systems and organs. The timely involvement of therapeutic arrangements, directed on removal of excessive copper from the patient's organism, may essentially improve the life quality and duration of this contingent of patients.

The aim of the work was to analyze clinical manifestations and course of Wilson's disease cases, genetically verified in children by detecting mutations of $A T P 7 B$ gene for improving its diagnostics.

\section{Materials and methods}

The material of the study was DNA of 25 children, 6-17 years old (14 boys and 11 girls), with clinical or biochemical manifestations, typical for Wilson's disease. Viral hepatitis, alcoholic cirrhosis, medicamentous lesion of the liver were excluded for all patients of the experimental group. Patients with neurological manifestations were selected by the method of genealogy analysis, and persons with disease manifestations in each generation that didn't prove the hereditary type of a sign or autosomal-recessive type of inheritance were excluded. There were taken registration cards, including information about age, gender, clinical manifestations and data of laboratory studies (biochemical indices of blood and urine, MRT data of brain of patients). The material for the study was taken after singing an informed consent and permission for DNA storage at a bank by parents. For taking a sample of DNA, there were used leukocytes of peripheral blood, 
washed in $2-5 \mathrm{ml}$ of venous blood by the method of enzymatic disintegration with $\mathrm{K}$ proteinase and further salting out [26]. The analysis of H1069Q mutation of ATP7B gene was carried out by PCR BI-PASA method. There were used two pairs of primers: external pair F-5' GGG CAG CTA GGA GAG AAG GAC 3', R-5' AGT TCT GCC TCA GGA GTG TGA CT 3', internal pair: F-5' GGA GGC CAG CAG TGA ACA A 3', R-5' GAC TGC CAC GCC CAA GGG G 3', 2xGreen master mix (ThermoScientific), in the automatic regime on the Thermocycler T-CY (Crea-Technology) with the following temperature parameters: $1-95^{\circ} \mathrm{C} 5 \mathrm{~min}, 2-94{ }^{\circ} \mathrm{C} 1 \mathrm{~min}, 3-30$ cycles $54^{\circ} 30 \mathrm{~s}, 72{ }^{\circ} \mathrm{C} 25 \mathrm{~s}$ [28]. Electrophoresis was carried out in $2 \%$ agarose gel. The presence of a fragment of 212 pairs of bases testifies to the absence of H1069Q mutation. The presence of a fragment of 181 pair of bases testifies to the presence of H1069Q mutation in the homozygous condition. Two fragments of 212 and 181 pairs of bases testify to the mutation in the heterozygous condition [24]. There was carried out the HRM analysis (high resolution melting) of exons 8 and 14 as to screening the presence of other allele variants. The obtained meting curves of persons from the experimental group were considered with ones of healthy persons, looking for differences in melting temperatures of DNA fragments. Differences in melting temperatures testify to the presence of different nucleotides in same gene locus. Samples with changed melting curves were further sequenced. 5 of 25 children with the high risk of Wilson's disease (with 3 points by the point scale) underwent the compete sequencing of $A T P 7 B$ gene at the base of Riga Stradins University. The primary sequence of DNA was realized by Senger's method. The analysis of obtained sequence diagrams was carried out in the program Chromas, UGENE. The multiplied leveling was realized in the program Muscle, pathogenicity was estimated by Mutation tester, Provean internet resources.

\section{Results of genetic testing of mutations of ATP7B gene and clinical characteristic of chil- dren with suspected Wilson's disease}

DNA extraction and molecular-genetic studies of gene mutations were realized at the base of the laboratory of genetic studies of SI «IHP NAMS of Ukraine». Patients were directed for observation from different regions of Ukraine, namely Lviv (8 persons), Zaporizhzhya (8 persons), Dnipro (3 persons), Rivne ( 3 persons), Khmelnytsky ( 2 persons) and Donetsk (1 person).

Nine ( 5 boys and 4 girls) of 25 children were homo- or heterozygous for mutation H1069Q of $A T P 7 B$ gene. According to the results of the molecular-genetic analysis, the pathogenic variant of $A T P 7 B$ p.His1069Q gene (at the level of cDNA c. 3207C >A), most spread in Europe, was confirmed in 9 child patients, including 4 cases of homozygosity. In one case H1069Q mutation was revealed with another allele variant of $A T P 7 B$ gene. The genetic diagnostic results of mutations of $A T P 7 B$ gene among child patients with Wilson's-Konovalov disease are presented in Table 1.

Table 1

Results of genetic diagnostic of mutations of $A T P 7 B$ gene among children with non-specific lesions of hepatobiliary system and suspected Wilson's-Konovalov disease

\begin{tabular}{cc}
\hline Genotype of ATP7B gene & Frequency \\
\cline { 2 - 2 } c. $3207 \mathrm{C}>\mathrm{A} / 3207 \mathrm{C}>\mathrm{A}$ & $\mathbf{N}(\mathbf{\%})$ \\
c. $3207 \mathrm{C}>\mathrm{A} / \mathrm{N}$ & $4(16)$ \\
c. $3207 \mathrm{C}>\mathrm{A} / 2304 \mathrm{dupC}$ & $3(12)$ \\
c. $3402 \mathrm{delC} / \mathrm{X}$ & $1(4)$ \\
$\mathrm{X} / \mathrm{X}$ & $1(4)$ \\
$\mathrm{N} / \mathrm{N}$ & $1(4)$ \\
Totally & $15(60)$ \\
\end{tabular}

The results of $A T P 7 B$ gene mutations testing among children with non-specific lesions of the hepatobiliary system, presented in Table 1, testify that the diagnosis of Wilson's disease was confirmed in 9 of 25 persons that are $36 \%$ because even at revealing one mutation in $A T P 7 B$ 
gene together with biochemical indicators, a patient takes 4 points by the point scale. One of patients didn't demonstrate any mutation in the coding sequence of $A T P 7 B$ gene, but the totality of biocemical indicators (copper in urine $227 \mathrm{mcg} /$ day, ALT - 1745 IU/1, AST - 873 IU/1, bilirubin $314 \mathrm{mcMol} / \mathrm{l}$ ) and clinical signs (liver cirrhosis, focal changes in the brain) and positive answer to the pathogenic therapy inclined to the Wilson's disease diagnosis. In this case a mutation in intron parts of the gene, not sequenced in this cohort of patients, are possible.

The obtained results demonstrated that the study of H1069Q major mutation of ATP7B gene is highly effective, and even revelation of this mutation in one allele is diagnostically significant at presence of minimal clinical changes and adds 1 point at the point diagnostic estimation.

The analysis of clinical manifestations of WD in children at the moment of genetic diagnostic was realized. The results are presented in Table 2.

Table 2

Clinical manifestation of the disease among children with the verified diagnosis of Wilson's disease

\begin{tabular}{|c|c|c|c|c|c|c|}
\hline $\begin{array}{l}\text { Sample } \\
\text { number }\end{array}$ & Genotype & Gender & $\begin{array}{c}\text { Age at } \\
\text { diagnostics }\end{array}$ & $\begin{array}{c}\text { Neurological } \\
\text { manifestations }\end{array}$ & $\begin{array}{l}\text { Lesions of hepa- } \\
\text { tobiliary system }\end{array}$ & Biochemical indices \\
\hline 1 & c. $3207 \mathrm{C}>\mathrm{A} / \mathrm{c} 2304 \mathrm{dupC}$ & $\mathrm{m}$ & 10 & Absent & Liver cirrhosis & $\begin{array}{c}\text { Ceruloplasmin } 0.1 \mathrm{~g} / 1 \text { (norm: } \\
0.2-0.6 \mathrm{~g} / \mathrm{l}) \text {, copper in blood } \\
33 \mathrm{mcg} / \mathrm{dl} \text { (norm: } 80-160 \mathrm{mcg} / \mathrm{l}) \text {. } \\
\text { Copper in urine }-961 \mathrm{mg} / \mathrm{day}, \\
\text { AST - } 70 \mathrm{IU} / 1, \mathrm{ALT}-164 \mathrm{IU} / \mathrm{l} \text {, } \\
\text { bilirubin } 12.4 \mathrm{mcMol} / 1\end{array}$ \\
\hline 2 & c. $3207 \mathrm{C}>\mathrm{A} / 3207 \mathrm{C}>\mathrm{A}$ & $\mathrm{m}$ & 17 & Absent & $\begin{array}{l}\text { Autoimmune } \\
\text { hepatitis }\end{array}$ & \\
\hline 3 & c. $3207 \mathrm{C}>\mathrm{A} / 3207 \mathrm{C}>\mathrm{A}$ & $\mathrm{f}$ & 14 & Absent & $\begin{array}{l}\text { Autoimmune } \\
\text { hepatitis }\end{array}$ & \\
\hline 4 & c. $3207 \mathrm{C}>\mathrm{A} / \mathrm{X}$ & $\mathrm{m}$ & 12 & Absent & $\begin{array}{l}\text { Fulminant hep- } \\
\text { atitis }\end{array}$ & \\
\hline 5 & c. $3207 \mathrm{C}>\mathrm{A} / \mathrm{X}$ & $\mathrm{f}$ & 14 & Absent & Liver cirrhosis & $\begin{array}{l}\text { Copper in urine } 1025 \mathrm{mg} / \text { day, } \\
\text { ceruloplasmin } 0,12 \mathrm{~g} / \mathrm{l}, \\
\mathrm{ALT}-64 \mathrm{IU} / 1, \mathrm{AST}-115 \mathrm{IU} / 1 \text {, } \\
\text { bilirubin } 25.8 \mathrm{mcMol} / 1\end{array}$ \\
\hline 6 & c. $3207 \mathrm{C}>\mathrm{A} / 3207 \mathrm{C}>\mathrm{A}$ & $\mathrm{m}$ & 6 & Absent & $\begin{array}{c}\text { Autoimmune } \\
\text { hepatitis }\end{array}$ & \\
\hline 7 & c. $3207 \mathrm{C}>\mathrm{A} / \mathrm{X}$ & $\mathrm{m}$ & 6 & Absent & $\begin{array}{l}\text { Autoimmune } \\
\text { hepatitis }\end{array}$ & \\
\hline 8 & c. $3207 \mathrm{C}>\mathrm{A} / 3207 \mathrm{C}>\mathrm{A}$ & $\mathrm{f}$ & 7 & Absent & $\begin{array}{l}\text { chronic } \\
\text { hepatitis }\end{array}$ & $\begin{array}{c}\text { Copper in urine } 175 \mathrm{mg} / \mathrm{day}, \\
\text { ceruloplasmin } 0.14 \mathrm{~g} / \mathrm{l} \\
\text { ALT }-118 \mathrm{IU} / 1, \mathrm{AST}-88 \mathrm{IU} / 1, \\
\text { bilirubin } 7.5 \mathrm{mcMol} / 1\end{array}$ \\
\hline 9 & c. $3402 \mathrm{delC} / \mathrm{X}$ & $\mathrm{f}$ & 13 & absent & $\begin{array}{l}\text { Liver cirrhosis/he- } \\
\text { molytic anemia }\end{array}$ & $\begin{array}{c}\text { Copper in urine } 1700 \mathrm{mg} / \mathrm{day}, \\
\text { ceruloplasmin less } 0.03 \mathrm{~g} / \mathrm{l}, \\
\text { ALT - } 86 \mathrm{IU} / 1, \mathrm{AST}-112 \mathrm{IU} / \mathrm{l} \text {, } \\
\text { bilirubin } 53 \mathrm{mcMol} / 1\end{array}$ \\
\hline 10 & $X \backslash X$ & $\mathrm{~m}$ & 16 & $\begin{array}{l}\text { Focal changes in } \\
\text { the brain bridge }\end{array}$ & Liver cirrhosis & $\begin{array}{c}\text { Copper in urine } 227 \mathrm{mcg} / \mathrm{day}, \\
\text { ALT }-1745 \mathrm{IU} / \mathrm{l}, \mathrm{AST}-873 \mathrm{IU} / \mathrm{l}, \\
\text { bilirubin } 314 \mathrm{mcMol} / 1\end{array}$ \\
\hline
\end{tabular}

In a half of confirmed WD cases, the clinical diagnosis was autoimmune hepatitis that, as we assume, indicated only on exclusion of other known factors of hepatobiliary disorders, but not the presence of immune reactions. The obtained results indicate the fact that at child age cases of Wilson's disease can be treated and observed as other diagnoses (namely, autoimmune hepatitis), if a doctor has no suspect about WD and doesn't direct patients to the correspondent examination.

It is necessary to pay attention, that among children with diagnosed WD of even teen age, there are no manifestations from the nervous system, excluding one case. None of the diagnosed 
patients with WD in child age demonstrated Kayser-Flescher rings on the cornea membrane. So, the approach, when at fixing copper metabolism disorders, the examination of an oculist is referent, is ineffective in all cases, described in the work.

\section{Discussion of the obtained results of testing ATP7B gene mutation and clinical character- istic of children with suspected Wilson's disease}

The genetic testing of $A T P 7 B$ gene is carried out one time and allows to reveal the disease before clinical signs appeared that is important for timely treatment and prevention of heavy lesions of the liver and neurological changes. Some mutations demonstrate the regional and ethnic difference. Among Europeans, the most spread mutation is p. His1069Gln (14 exon), whereas in Asia - p. Arg778Leu (8 exon) [27], and in Brazil - p. His1069Gln and 3402delC in exon 15 [21, 27]. For the studied sample, it is informative to analyze H1069Q mutation. Such analysis is available and may be used for both confirmation and exclusion of this disease and need wider prescription. We also predict higher frequency of this nosology in Ukraine and its hypo diagnostics. The previously established frequency of heterozygous carriers of H1069Q mutation of ATP7B gene is 1 for 58 that is higher than in other populations $[23,24]$. The frequency of Wilson's disease heterozygous carriers, taking into account other mutations, may reach 1 for 40, so the disease occurrence is 1 for 6500 . Taking into account the population size, 4-6 cases must be diagnosed in the Lviv region only, and near 350 must be observed, among which 50-90 persons of child age. Unfortunately, statistical data of this nosology are limited.

The genetic defect of a patient is present from birth, but this disease is mainly diagnosed already in adult age.

During three years, Wilson's disease in child age was confirmed in 10 persons of 25 suspected, mainly in the second life decade. Three children were younger 10 years. These data testify to the necessity for pediatricians to be more careful as to the diagnostic of this disease. All children demonstrated liver lesions that varied from cryptogenic hepatitis to cirrhosis and also different variations of growing transaminase level in blood serum. We find expedient to carry out the differential diagnostics and genetic testing of major mutations of $A T P 7 B$ gene in all cases of idiopathic hepatitis.

According to ESPGHAN recommendations of 2018, Wilson's disease must be taken into account with the high verification degree (class A) in the differential diagnostics in children, older 1 year with signs of hepatic illness, starting from the symptomless growth of transaminase up to cirrhosis with hepatosplenomegaly and ascites or acute hepatic failure [2].

Thus, WD may be diagnosed in different ages, including child one. Among all cases, verified at SI "Institute of Hereditary Pathology of NAMSU", less than one third was diagnosed in child age. According to the obtained results, WD is manifested in the young school age (6-7 years), but manifestations are non-specific, related to lesions of the hepatobiliary system of unexplained genesis.

The sample doesn't include children with idiopathic cognitive or psychiatric disorders, but the literature presents cases, when the first symptom of the disease was behavioral changes, explained by the pubertal period. That is why Wilson's disease must be also excluded in teenagers with unknown cognitive, psychiatric or motor disorders.

According to ESPGHAN recommendations, the diagnostic testing must also include serum transaminase, total bilirubin, alkaline phosphatase, prothrombin time, ceruloplasmin and daily urine by the copper content.

Ferenzi's evaluation system is recommended for using for diagnosing Wilson's disease in child age, and it is accented, that the analysis of $A T P 7 B$ gene mutations facilitates the diagnostics [10].

In a case of revealing WD it is recommended to carry out the medical-genetic consulting and study of mutations in proband's relatives, because the disease is inherited by the autosomal-recessive type that is equally spread among males and females. The revelation of mutations in a proband also testifies to the fact that both parents are carriers of one of mutations and the risk of ill child birth is $25 \%$. During the period of our work we revealed sibs with homozygous H1069Q mutation. At the moment of genetic diagnostic any clinical signs of the disease were present.

After confirming the diagnosis in a proband, Wilson's disease must be looked for in first degree relatives. There is information about cases of diagnosing Wilson's disease at the symptomless clinical course in relatives of ill children $[11,12,25]$. 
None patients in our study demonstrated expressed neurological signs at disease manifestation. It may be explained by the fact that the excessive copper accumulation in first turn takes place in the liver as its main depot, starting from the breast age, when the ration is enriched with food products, containing this microelement. When the copper overload continues to grow, it accumulates in other organs, such as brain, kidney, spleen, heart, eye cornea. At the absence of diagnostics and adequate therapy, cirrhosis, hepatic failure and irreversible changes in the brain take place [2, 5, 21].

Taking into account that none diagnosed patients with WD demonstrated Kayser-Fleischer rings on the cornea membrane in child age, the referent oculist's examination at fixing copper disorders is ineffective. The main test for diagnosing WD in children is results of the genetic analysis of $A T P 7 B$ gene mutations.

\section{Conclusions}

9/25 children (36\%) with clinical manifestations of Wilson's disease demonstrated major mutations of $A T P 7 B$ gene and genetically verified diagnosis of this monogenic pathology.

The clinical manifestation in all 10 with the verified diagnosis of Wilson's disease was characterized by disorders of the hepatobiliary system that are $100 \%$, and only in $1(10 \%)-$ by changes of the nervous system.

For cases of the transaminase level increase in children, even at the normal bilirubin level and negative tests for virus's hepatitis, it is recommended to carry out genetic testing for Wilson's disease.

Taking into account the availability of the therapy, it is necessary to raise carefulness of pediatricians, child gastroenterologists and infectious diseases specialists as to diagnosing Wilson's disease in child age.

Taking into account the wide spectrum of mutations (more than 500); it is necessary to establish the list of most often ones for introducing in medical-genetic consulting practice for the fast and economically effective diagnostics. Such researches have not been realized in Ukraine that is why there is no unambiguous answer about the disease prevalence. We assume that a part of revealed cases of WD suspect may have disorders in other not tested gene parts. This work also doesn't exclude the presence of big deletions and duplications that can be also a genetic factor of P-type ATPase function disorder in some patients. The work is also limited by the cohort of examined child patients, namely children, consulted at highly specialized health protection institutions, knowing about WD. Taking into account the obtained results, it will be expedient to carry out the genetic study in the wide sample of child patients with the diagnosis of autoimmune, cryptogenic hepatitis. We don't exclude that the carefulness as to the needs of excluding WD in children with hepatic idiopathic diseases is low at the level of district infectious diseases specialists and gastroenterologists.

\section{References}

[1] Roberts, E. A., Socha, P. (2017). Wilson disease in children. Handbook of Clinical Neurology, 141-156. doi: https://doi. org/10.1016/b978-0-444-63625-6.00012-4

[2] Gao, J., Brackley, S., Mann, J. P. (2018). The global prevalence of Wilson disease from next-generation sequencing data. Genetics in Medicine, 21 (5), 1155-1163. doi: https://doi.org/10.1038/s41436-018-0309-9

[3] Yuan, Z.-F., Wu, W., Yu, Y.-L., Shen, J., Mao, S.-S., Gao, F., Xia, Z.-Z. (2015). Novel mutations of the ATP7B gene in Han Chinese families with pre-symptomatic Wilson's disease. World Journal of Pediatrics, 11 (3), 255-260. doi: https://oi.org/10.1007/ s12519-015-0031-5

[4] Socha, P., Janczyk, W., Dhawan, A., Baumann, U., D’Antiga, L., Tanner, S. et. al. (2018). Wilson's Disease in Children. Journal of Pediatric Gastroenterology and Nutrition, 66 (2), 334-344. doi: https://doi.org/10.1097/mpg.0000000000001787

[5] Trufanov, Y. O. (2018). Diagnosis and treatment: wilson's disease. World of Medicine and Biology, 4 (66), 117-120. doi: https:// doi.org/10.26724/2079-8334-2018-4-66-117-120

[6] Trufanov, Ye. A., Penner, V. A., Mishchenko, M. V., Lomova, I. V. (2012). Klinicheskiy sluchay bolezni Konovalova-Vilsona: trudnosti diagnostiki. Ukrayinskyi medychnyi almanakh, 15 (5), 460-462.

[7] Seo, J. K. (2012). Diagnosis of Wilson Disease in Young Children: Molecular Genetic Testing and a Paradigm Shift from the Laboratory Diagnosis. Pediatric Gastroenterology, Hepatology \& Nutrition, 15 (4), 197. doi: https:/doi.org/10.5223/ pghn.2012.15.4.197 
[8] Li, H., Liu, L., Li, Y., He, S., Liu, Y., Li, J. et. al. (2018). Familial screening of children with Wilson disease. Medicine, 97 (27), e11405. doi: https://doi.org/10.1097/md.0000000000011405

[9] Ministerstvo okhorony zdorovia Ukrainy. Nakaz vid 26 lypnia 2016 roku No. 769. Unifikovanyi klinichnyi protokol pervynnoi ta vtorynnoi (spetsializovanoi) medychnoi dopomohy. Khvoroba Vilsona.

[10] Ferenci, P., Caca, K., Loudianos, G., Mieli-Vergani, G., Tanner, S., Sternlieb, I. et. al. (2003). Diagnosis and phenotypic classification of Wilson disease1. Liver International, 23 (3), 139-142. doi: https://doi.org/10.1034/j.1600-0676.2003.00824.x

[11] Brunet, A.-S., Marotte, S., Guillaud, O., Lachaux, A. (2012). Familial screening in Wilson's disease: Think at the previous generation! Journal of Hepatology, 57 (6), 1394-1395. doi: https://doi.org/10.1016/j.jhep.2012.07.011

[12] Roberts, E. A., Schilsky, M. L. (2008). Diagnosis and treatment of Wilson disease: An update. Hepatology, 47 (6), $2089-2111$. doi: https://doi.org/10.1002/hep.22261

[13] Patil, M., Sheth, K. A., Krishnamurthy, A. C., Devarbhavi, H. (2013). A Review and Current Perspective on Wilson Disease. Journal of Clinical and Experimental Hepatology, 3 (4), 321-336. doi: https://doi.org/10.1016/j.jceh.2013.06.002

[14] Alam, S. T., Rahman, M. M., Islam, K. A. et. al. (2014). Neurologic manifestations, diagnosis and management of Wilson's disease in children: an update. Mymensingh Med. J., 23, 195-203.

[15] Hedera, P. (2017). Update on the clinical management of Wilson's disease. The Application of Clinical Genetics, $10,9-19$. doi: https://doi.org/10.2147/tacg.s79121

[16] Liu, J., Luan, J., Zhou, X., Cui, Y., Han, J. (2017). Epidemiology, diagnosis, and treatment of Wilson's disease. Intractable \& Rare Diseases Research, 6 (4), 249-255. doi: https://doi.org/10.5582/irdr.2017.01057

[17] Ponomarev, V. V. (2010). Bolezn Konovalova-Vilsona: “velikiy khameleon”. Mezhdunarodnyi nevrologicheskiy zhurnal, 3 (33), 117-122.

[18] Rodriguez-Castro, K. I. (2015). Wilson's disease: A review of what we have learned. World Journal of Hepatology, 7 (29), 2859. doi: https://doi.org/10.4254/wjh.v7.i29.2859

[19] Aggarwal, A., Bhatt, M. (2013). Update on Wilson Disease. Metal Related Neurodegenerative Disease, 313-348. doi: https:// doi.org/10.1016/b978-0-12-410502-7.00014-4

[20] De Bem, R. S., Raskin, S., Muzzillo, D. A., Deguti, M. M., Cancado, E. L. R., Araujo, T. F., Nakhle, M. C. et. al. (2013). Wilson's disease in Southern Brazil: genotype-phenotype correlation and description of two novel mutations in ATP7B gene. Arquivos de Neuro-Psiquiatria, 71 (8), 503-507. doi: https://doi.org/10.1590/0004-282x20130078

[21] Deguti, M. M., Genschel, J., Cancado, E. L. R., Barbosa, E. R., Bochow, B., Mucenic, M. et. al. (2004). Wilson disease: Novel mutations in theATP7B gene and clinical correlation in Brazilian patients. Human Mutation, 23 (4), 398-398. doi: https:// doi.org/10.1002/humu.9227

[22] EASL Clinical Practice Guidelines: Wilson's disease (2012). Journal of Hepatology, 56 (3), 671-685. doi: https://doi.org/ 10.1016/j.jhep.2011.11.007

[23] Haiboniuk, I. (2019). Spectrum and frequency of ATP7B gene mutations in various populations and ethnic groups. Visnyk of Lviv University. Biological Series, 80, 3-11. doi: https://doi.org/10.30970/vlubs.2019.80.01

[24] Haiboniuk, I., Makukh, H., Tyrkus, M., Tretiak, B., Jadzhyn, L. (2019). Mutations H1069Q of ATP7B gene and C282Y and H63D of HFE gene in persons with hepatobilary diseases of undefined genesis. Bulletin of Problems Biology and Medicine, 1 (2), 224. doi: https://doi.org/10.29254/2077-4214-2019-1-2-149-224-229

[25] Li, H., Liu, L., Li, Y., He, S., Liu, Y., Li, J. et. al. (2018). Familial screening of children with Wilson disease. Medicine, 97 (27), e11405. doi: https://doi.org/10.1097/md.0000000000011405

[26] Makukh, H. V., Zastavna, D. V., Tyrkus, M. Y., Tretiak, B. I., Chorna, L. B. (2008). Pat. No. 32044 UA. Method for separation of DNA from leucocytes of peripheral blood. No. u200801896; declareted: 14.02.2008; published: 25.04.2008, Bul. No. 8.

[27] Wilson's Disease Scoring System. Available at: https://gastroliver.medicine.ufl.edu/hepatology/for-physicians/wilsons-disease-scoring-system/

[28] Polakova, H., Katrincsakova, B., Minarik, G., Ferakova, E., Ficek, A., Baldovic, M., Kádasi, L. (2007). Detection of His1069Gln mutation in Wilson disease by bidirectional PCR amplification of specific alleles (BI-PASA) test. Gen. Physiol. Biophys, 26 (2), 91-96. 